\title{
FIFTEENTH ANNUAL NESTBOX REPORT OF THE BRANDON JUNIOR BIRDERS — 1975
}

\author{
by Mrs. JOHN LANE* and SEAN BLACK**
}

During the winter months of 1975 , very little field work was accomplished because of the heavy snowfall. The Juniors met several Saturday mornings to build nestboxes and on two other occasions, they gathered for an educational and social time. New members were introduced and adult helpers, Mr. W. E. Forsythe, Mr. H. Watson and Mr. John Plum, were invited. Mr. Forsythe continues to donate a steady supply of good boxes and $\mathrm{Mr}$. Plum still rounds up quantities of building materials. During one of the get-togethers, Mrs. Lane presented an illustrated talk to the boys on the life of Ernest Thompson Seton, stressing his love of the Carberry spruce woods and sandhill areas, where now many of the Junior Birders' most productive nestlines are located.

Due to the illness and subsequent death of John Lane, a large segment of the bluebird nestlines was neglected this summer. However, some good early spring field trips were enjoyed during which 5 nestboxes were replaced, 43 new bluebird boxes and 6 Wood Duck boxes were set out.

* 1701 Lorne Avenue.

Brandon, Manitoba.

*212 - 13th Street East, Brandon, Manitoba.
May 17 and May 19 were the last field trips of the Brandon Junior Birders with their director. On these 2 full-day outings, 9:00 a.m. to 4:30 p.m., much work was accomplished, including the moving of boxes from the Trans-Canada Highway east of Brandon, where four lanes are being constructed.

The regular helpers had a busy summer and have sent in their reports which are greatly appreciated. Mr. and Mrs. Ed Robinson, Wawanesa, report 58 Mountain Bluebird nestings and 2 Eastern Bluebird nestings. An interesting highlight on their nestline was the unusual behaviour of a male Mountain Bluebird. This bird would respond to Mr. Robinson's whistle and fly to him, alighting on his head or his hand repeatedly throughout their visits.

Mr. and Mrs. Art Michie, Souris, reported 74 Mountain nestings and no Eastern nestings. Again there was a recurrence of black flies (Simulium venustum) causing 31 deaths of nestlings.

Mr. and Mrs. Les North, Pratt, reported 25 Mountain Bluebird nestings and 1 Eastern.

Mr. and Mrs. Jim Spear, Russell, found 41 nestings of Mountain Bluebirds, 2 Eastern, and 1 crossbreeding (Mountain male $\mathrm{x}$ Eastern female). 


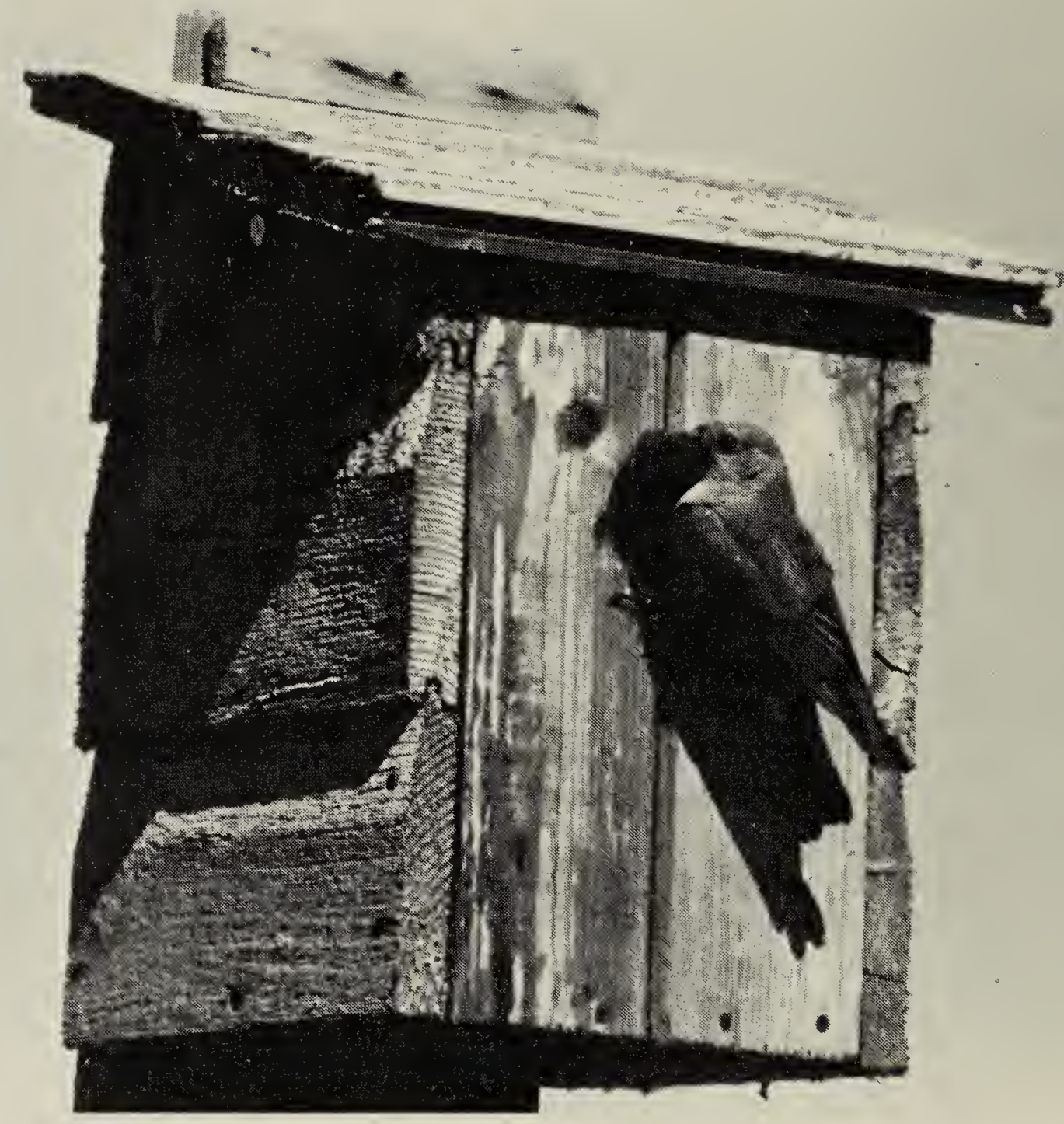

Mountain Bluebird at Kargut box.

R. J. Long

At a meeting called in mid-August by the Brandon Natural History Society and members of the Science department of Brandon University, and chaired by Dr. R. K. Lane, Edmonton, Alberta, a plan was initiated to carry on the work of the late John Lane and his Junior Birders. Volunteers committed themselves to care for allotted portions of the extensive nestlines, to keep records and, in some areas, to promote scientific research.

These volunteers, including Junior Birders, made some early fall checks, but because of the date, could not be specific as to the species of bluebirds. However, from the nature of vacated nests, they could be identified as bluebird nestings and for this year are listed merely as bluebird nestings.
Two Junior Birders, Chris Martin and Tony Burton, checked old No. 1 Highway Carberry - 15 bluebird nestings. On the Carberry-Glenboro and Minnedosa-Erickson lines, Tony listed 34 bluebird nestings. Barbara Robinson, Brandon, reported 66 bluebird nestings in the Camp Hughes area. Northwest of Brandon in small areas, Rivers and Hamiota, Mr. and Mrs. R. H. Patmore, Brandon, reported 4 bluebird nestings. From the Austin-Holland line, volunteers $\mathrm{Mr}$. and Mrs. Wayne Brown, Austin, sent in their late fall findings of 21 bluebird nestings. The A. M. Bauman family of Brandon reported 3 Mountain Bluebirds and 1 bluebird nesting on No. 10 line south of Brandon. 
The total number of nestboxes checked for 1975 by regulars and volunteers was 789 . A summary of the occupants shows: Mountain Bluebirds 201: Eastern Bluebirds 5; cross breeding 1: Bluebirds (either species) 141; Tree Swallows 251; House Wrens 14; House Sparrows 74; mice 37; Starlings 2; grain 2; empty 37 ; vandalized 24 .

If the good fall weather holds, large portions of the neglected nestboxes will be cleaned out by volunteers, ready for an active summer in 1976.
The Junior Birders were represented by Chris Martin and Daryl Neustater at the 93rd Stated Meeting of the A.O.U. at the University of Manitoba, Winnipeg, Their display showed the growth of their club's work through 15 years. Dr. David Krieg of State University, New York, presented his paper, "Species-recognition: Behaviour of Territorial Eastern and Mountain Bluebirds". The research was the result of studies done on our nestlines.

\section{EASTERN PHOEBES IN BIRCH HILLS MUNICIPALITY}

by MOE MARESCHAL and STUDENTS*

This Biology 20 project was inspried by J. A. Wedgwood's article on nighthawks in the Blue Jay of June, 1973. The Eastern Phoebe has been observed relatively frequently in the past in our area and it was decided to investigate the frequency of this bird in 1975. To do this we searched nesting sites in abandoned farms and under bridges. A large part of the Birch Hills Municipality was subdivided and one group was assigned to each division.

Group 1: Linda Stobbs and Cheryl Rude. Our first trip was made on June 11. In this trip we covered 42 miles and looked in 11 places, most of them containing more than one building. On

"Cheryl Rude, Linda Stobbs, Kathy Haug, Bev Miller, Debbie Braaten, Donna Silde, Bonnie Hovdebo, Lynn Njaa and Donna Kormish. Birch Hills Composite High School,

Birch Hills, Sask. SOJ OLO the outside of one large house, under a roof ledge, we found a phoebe nest containing three young. We saw the mother there also. In a couple of bins and old houses we found six Barn Swallow nests. We did not check the nests for contents. We also checked six bridges and saw birds flying out.

On Saturday, June 14, we tried to check the nests under the six bridges but the water was too deep. We checked a seventh bridge but no nests or birds were found (22 miles).

On Monday, June 16, we again checked six bridges and observed the birds we scared out. At two different bridges we saw two phoebes. Other birds we saw included Barn Swallows and sparrows. We could hear baby birds but could not see the exact location of the nests (15 miles).

We covered a total of 79 miles or approximately 20 square miles. 